\title{
Medicine and Religion
}

\section{A hand and a name}

\author{
AHRON FRIEDBERG
}

As usual, I went to play the guitar this evening for the patients at University College Hospital. Since I came to Britain as a foreign transfer student from the United States I have changed many of my ways, but this music routine has become a habit. When the sun sets on Friday evening the minstrel who rests quietly in me during the week wakes up. Lately, I have been playing the guitar for patients in ward $4 / 3$, a ward primarily for chronically ill patients. There is a sincerity about people who are close to death that I enjoy because I have a sense that my songs resonate more deeply in them. Tonight I was performing for two men and a woman in the back left hand corner of the alcove off to the left when you walk into the ward, and the patient in the bed behind me began to die. I was certain of this as a nosy old woman in the bed next to her announced that she was dying and because a young nurse came and drew the curtains around her and stayed with her. The staff nurse asked me please to leave, but on my request permitted me to remain quietly in my place.

While Mrs A was dying things were much the same in the ward. Patients continued to be patients, and nurses busily attended to their needs. Except for me and the nosy old woman, no one displayed any interest. I listened with obvious attention, concentration fixed on what was happening behind the curtain. I recalled how Monet had sat by the side of his dying wife, held her hand and watched her skin change from pink to pale to an ash blue, watched the red life flow from her veins, and whispered her name. Mrs A died quietly, and it was not until the young nurse stepped out from behind the curtain that I knew for sure of her death. The body was left untouched for an hour, then removed in a deep box. Within ten minutes a fresh and empty bed was in place, and the nosy old woman talked nosily over it about the happening to a kind listener. Eventually, I left the hospital feeling an earnest sorrow about the death of a good person whom I knew from my previous visits to the ward, but I was also impressed by certain aspects of her death.

\section{Importance of customs and communication}

The patient was not alone at her death. Although Mrs A was separated from the other patients by a curtain drawn around her, as she entered into the final stage of her death, a nurse remained with her. In fact, from the time Mrs A entered the ward until her death there probably never was a time when she was separated from her ward mates, except during private treatment, and then, of course, she would at least have had an attendant with her. Mrs A was visited regularly by her husband four times a week, and she was visited frequently by friends.

Dartmouth College, New Hampshire, USA AHRON FRIEDBERG, medical student

Correspondence to: Hinman Box 2010, Dartmouth College, Hanover, New Hampshire 03755, USA.
Still, visiting hours are limited, friends are always on the run, and even the closest family member has other responsibilities to attend to. (I do not know why Mr A was not present at his wife's death.) Mrs A was quite a good listener and would often play the nosy old woman's confidante. When she was admitted to the ward she partook of the regular teas at $800 \mathrm{am}, 1030 \mathrm{am}, 1200$ noon, $330 \mathrm{pm}, 600 \mathrm{pm}$, and $800 \mathrm{pm}$. There is also tea at $600 \mathrm{am}$ for early risers and a night cap at $1000 \mathrm{pm}$, and patients may have tea more frequently if they desire. These are social times for patients. For some patients an invitation to tea is a chance to forget where they are and to partake in a custom. For others tea is not so much a time to forget where they are as it is to give the hospital a value beyond that of a place where people go to get well. Idle talk has its therapeutic value as a communication, allowing patients to share their worries with the people who may have similar concerns. When Mrs A wanted to know the goings on in the rest of the hospital and the events of the day she could plug into the hospital radio station, which broadcasts from 1000 am to $1000 \mathrm{pm}$, Monday to Friday, and does a children's programme on Saturday morning. Mrs A remarked to me once that she felt part of the hospital, connected to and comfortable with her surroundings. Simply, all this made the hospital more like a home for her with many of the warmest connotations of the word.

I am struck by how different Mrs A's experience would have been if she had been admitted to the Mary Hitchcock Memorial Hospital in New Hampshire, the hospital that I am associated with at home. She might have started out in a "ward" with half a dozen patients and, as her condition degenerated, she would probably have been moved to a private or semiprivate room. I have found that even in wards where people are inclined to be friendly there is little to promote communication and contact among them. Americans do not have a tea time, and coffee breaks are for people hard at work. Also, American hospitals do not usually have their own private radio stations. At Mary Hitchcock patients do have their own private televisions. One effect of this, however, is to separate them even more from their room mates and surroundings and to encourage solitude and private thought. There is only one television set in ward $4 / 3$, and this is in the day room. Patients who are not bedridden may watch a programme there, but the room functions more as a privileged space where patients go to get away from the sickness that surrounds them and be with other patients fortunate enough to move about.

\section{Learning to die}

In a private room the patient is cut off from people except for treatment and check ups from the hospital staff and for visits. A danger of this is that it may make the patient like a hermit. Metaphorically, this annihilates the patient as a person before the human being is dead because a person exists as a person only in his relation with other people: the self by itself is no self. Wordsworth's nuns may "fret not in their convent's narrow room." Unlike patients, however, they are not confined by physical necessity. In the wards that I have observed at University 
College Hospital there is at least a recognition of this aspect of the patient and an eagerness to respond to him as a person.

Furthermore, the fact that Mrs A died in the ward made the other patients in 4/3 aware of, and even part of, the final stage of death. I write "the final stage of death" because this is how another patient, Mr B, a philosophical sort, had previously described a person's last hours. As he explained, life is a process of dying for from the moment we are born we begin to die. Therefore, if we struggle with the fact of our death and understand how to die then we will know how to live as well. This is perhaps a too simple idea, but it is right, I think, in the most important sense of what it means to be right. When Mr B was admitted to ward $4 / 3$ he was greatly distressed. After witnessing the death of several patients in the ward in the course of three weeks he was considerably less upset. I don't mean to suggest that if a patient reconciles himself with his anxieties about death then "tout est pour le mieux dans le meilleur des mondes possibles," or that the thought of dying was the cause of his psychological distress. In our initial conversations he seemed partly just ill at ease with his new surroundings. Being in the presence of other dying patients, however, seemed to relieve some of what $\mathrm{Mr}$ B described as "the awful fear of death's awesome mystery."

We (and I mean the royalist "we") have isolated death, removed it along with germs and viruses from our daily lives. Death was never as common around the house as the cold, but children were once as comfortable at play in a graveyard as in the garden behind the town church. We have become xenophobic of death and speak of it as something that is foreign to us. I was told that Mrs A "passed away" and heard that $\operatorname{Dr} C$ "is gone." It is as though to speak directly of death, to call death "death," enacts the word.

My experience with dying patients has been limited in that my role of minstrel usually maintains a distance between me and the patients, and the relationship is similar in this small respect to that between a doctor and a patient. I remember, though, a visit to my grandfather when he was dying in the intensive care unit at Columbia Presbyterian Hospital. I was upset not so much by the tubes feeding him air or by the needles nourishing him with colourless liquid as by a feeling that I was unable to feel his dying. I was told by the nurse not to touch him, not to disturb him. My 10 year old brother was ordered not to come into the room but to watch from the other side of the window. Who was being protected? My brother? My grandfather? The Thursday before Mrs A died she was visited by her son and his children. One of them, a boy of 5, played merrily at Grandma's feet, unconcerned though curious about the happenings. There was a deep acknowledgment when their wide eyes met.

Later in the evening I caught up with the young nurse who had attended to Mrs A at her death. We spoke about the "medic" disco at Camden Palace sponsored to raise money for research into diabetes and of our clever friend who had borrowed an intravenous fluid bottle to dispense gin at the affair. Then I asked her if Mrs A had said anything before dying. The young nurse wondered for the moment of a minute, perhaps as much about my interest in Mrs A as anything else, and replied cautiously that she didn't think so. We talked some more, and I reminded her of the time when old Miss $M$ had said to me, "I don't suppose you'd like to give an old lady a little kiss," and how I had kissed her and said, "I don't suppose you'd like to give a young medic a little kiss," and how she had done. Then I asked, gently, if anything special had happened during Mrs A's death. She was quiet, and I could feel a subtle tension in our silence. I waited. The young nurse said that Mrs A's death was usual. She had sat beside the dying woman, held her hand, and whispered her name.

\section{The stigmata: pathology or miracle?}

\section{J SIMPSON}

The medical approach towards religious phenomena is often to categorise them as "illnesses." This may be seen in the diagnosis of St Paul as having epilepsy and of Joan of Arc as having schizophrenia. Is there, however, a pathological process in religious stigmatisation? Stigmata are the wounds of Christ appearing on the body; they may include bleeding marks or holes on the hands, feet, and side and marks on the forehead and shoulder - the sites of the crown of thorns and cross respectively.

Imbert-Gourbeyre found that of the 321 people with stigmata that he discovered since the time of St Francis, 41 were men and 280 were women and these during their reproductive years. They were mainly from Italy, followed by France, Spain, Germany, Belgium, Portugal, Switzerland, Holland, Hungary, and Peru in that order.' Few people with stigmata have been beatified or canonised, and the Catholic Church teaches that there is no intrinsic connection between sanctity and stigmatisation. ${ }^{2}$ The sites of the stigmata are interesting, as the work of Barbet on cadavers $^{3}$ and evidence from the Shroud of Turin ${ }^{4}$ suggest that Christ had nails through his wrists whereas people with stigmata have palm wounds. The site of the lance wound is omitted in the Bible but changes, according to the current belief, from right or left hypochondrium to over the heart in those with stigmata. ${ }^{2}$ The

Drug Dependency Treatment Unit, St George's Hospital, London SW17 0QT C J SIMPSON, MB, BS, registrar wounds tend to change with the years; some bleed permanently and some just on Fridays. They normally appear when the person is in what is called "ecstasy."

St Francis of Assisi (1182 to 1226) is thought to have been the first person to receive stigmata unless St Paul implied that he had them when he wrote "I bear the marks of the Lord Jesus in my body." St Francis developed the stigmata during an ecstatic vision in 1224, when they were seen by a friend, Brother Leo, whose own handwritten note (the authenticity of which is uncontested) vouches for their reality. ${ }^{6}$ They were also seen by many after his death and were described two years after his death in his first biography: "The marks on the hands were round on the inner side, but on the outer side they were elongated: and some small pieces of flesh took on the appearance of the ends of the nails, bent and driven back and rising above the rest of the flesh."

Among famous nineteenth century examples was a Belgian girl called Louise Lateau (1850 to 1883), who bled every Friday except for two from 1868 to 1883 . She was observed by various eminent Belgian doctors. ${ }^{8}$ A German peasant girl called Therese Neumann (1898 to 1962) was bedridden from several head injuries when she developed the stigmata in 1926. Blood started to come from her side during an ecstatic vision, and a few weeks later she developed the hand and feet wounds. From then on they bled regularly on Fridays until her death. ${ }^{9}$ Her doctor diagnosed her initially as having "hysteria traumatica" for insurance purposes, though after the stigmata appeared he changed his mind. ${ }^{10}$

Padre Pio (1887 to 1968) was also of peasant stock. His biographies describe him as always having been spiritually 